\title{
Social and Biological Context of Physical Culture and Sport
}

\author{
Jerzy Kosiewicz
}

Josef Pilsudski University of Physical Education in Warsaw, Poland

Author underlines that biological sciences connected with the human being are traditionally - after MacFadden, among others - counted among physical culture sciences. Because of the bodily foundations of human physical activity, they perform - shortly speaking - a significant cognitive function: they describe natural foundations of particular forms of movement. In spite of the fact that knowledge in that respect is extremely important for multiform human activity in the field of physical culture, it is not knowledge of cultural character. From the formal (that is, institutional) viewpoint it is strictly connected with culture studies, but it has separate methodological and theoretical assumptions. Knowledge of that type is focused on the human organism and not on effects of mental, axiocreative, symbolic activity of the human being entangled in social relations. It includes auxiliary data which support practical - that is, in that case, physical, bodily - activity. Its reception of axiological (ethical and aesthetical), social (philosophical, sociological, pedagogical, historical \{universal or strictly defined - referring e.g. to art and literature with the connected theories\} or political) character is dealt with by the humanities (in other words: social sciences) constituting an immanent and the fundamental - and hence the most important - part of culture studies. Putting stress on alleged superiority and the dominating role of natural (biological in that case) sciences within physical culture sciences and the connected marginalization of the humanities - which constitute, after all, a necessary and hence an unquestionable foundation for culture studies, their essence and objectivisation - is, euphemistically speaking, a clear shortcoming in the field of science studies.

The abovementioned exaltation and aspirations for superiority, as well as deepening and more and more aggressive marginalization of the humanities (understood in that paper as a synonym for social sciences) in the field of physical culture sciences may lead to the separation of biological sciences.

philosophy, sport, significance, unity, embodiment, aesthetics of experience

The terms "physical culture" and "sport" are interpreted in multiple ways. Sometimes - in a particular context of justification - they are understood as synonyms, whereas on other occasions they are presented as terms of different, sometimes even considerably different, content.

Using an association referring to philosophy and - even more - to the sociology of culture, one can proclaim that the term "physical culture" is associated, first of all (referring to the etymology of the word "culture"), with colo ere of the human body - that is, with cultivation and taking care of human physis - obviously in the context of social and natural environment. 
This refers, according to this interpretation, to actions concerning the body, activities of autotelic character (constituting aims in themselves) focused mainly on culturally determined physical fitness (of non-professional character, which means in that case that it is not connected with material benefits), on aesthetics of the body and somatic health, also taking into account relations with the mind and social influences. Sport can be treated as a cultural phenomenon making use of outstanding and sublimated qualities of the human subject in order to achieve aims of pragmatic, measurable and discretionary character, which are inspired by and rooted in the context of social expectations. This refers to projected tasks, aspirations - that is, to the process aimed at their realization and to results achieved for that reason. They result, however, not so much from pragmatic needs, but rather from cultural ones ${ }^{1}$.

What is important in that respect - as well as in the other forms of physical culture - is the cultural context of the linked influence of social expectations and of aspirations which are mediated by accepted and historically, geographically, ethnically, politically, religiously or ideologically determined conventions which regulate and consolidate existing patterns of behaviour. The aim of those conventions is also the stimulation of creative activity, as well as popularization, nurturing and sublimation of the existing tradition, which is more or less spectacular and more or less mature in its identity.

Sport according to that interpretation - unlike other forms of physical culture - is associated solely with highly competitive, professional, spectacular or Olympic sport ${ }^{2}$.

\footnotetext{
${ }^{1}$ Qualities of sport are discussed more extensively in Kosiewicz, J. (2004b). The Universals of Sport - from Realism to Nominalism, in: Philosophy of Sport and Other Essays (Eds. Macura D., Hosta M.), Ljubljana, Faculty of Sport, University of Ljubljana.

${ }^{2}$ In the main text the notion of sport is discussed in an abbreviated way in order to adjust it to the central thought, to the content of the argument. In literature on the subject there are many more interpretations. For example, I can quote a description characteristic for sport social sciences, which is presented by D. Malcolm (2008, pp. 238-239) referring to A. Guttmann (2004), B. D. McPherson (1989) and N. Elias and E. Dunning (1986). He proclaims that it is common practice for the term "sport" to be used interchangeably with the terms play and game, whereas he is of the opinion that these are different notions, in spite of the fact that attempts at defining sport usually refer it qualities to the abovementioned terms. Malcolm writes - referring to Guttmann that the most general from among the non-utilitarian forms of activity of physical and mental character is the category of play. It has strictly autotelic - and not instrumental - qualities. It refers neither to health-oriented aims, nor to personal development, nor to physical or mental fitness, nor to earning for a living. It results from that, for example, that school and extra-school physical education or professional sport are not forms of play.
}

Play - as Malcolm proclaims after Guttmann - can come into existence in a spontaneous or an organized way. If play has organized character, we are dealing with a game. A game can be based on competition (competitive game) or take place without it (non-competitive game). The term refers to various activities - competition (like popular pole-vault competitions), fight, contest, strictly physical rivalry (like in contact- and non-contact sports) and intellectual rivalry (I would like to add that it can also have mixed character).

However Malcolm, who presents Guttmann's views, is of the opinion that, in spite of the fact that indubitably there is an intellectual component in sport, its character is determined by physical effort, which is immanently integrated into its structure (except of chess and bridge as a sport) and which is based on specific bodily fitness and developed skills. However, the abovementioned rivalry - in contrast to real fight or war - is based on playful game. It takes place in a joyful way. It has also qualities which are characteristic for play - autotelic values.

Guttmann creates a very general and, simultaneously, one-sided definition of sport, which passes over traits of highly qualified, highly competitive, professional, Olympic or spectacular sport. He proclaims that sport can be defined as an activity including competition, fight or contest of organized character, rivalry including elements of joyful game and play of non-utilitarian character, where physical competences (conditions) took precedence over intellectual ones ("sports can be defined as organized contests of a playful, non-utilitarian character in which the physical demands outweigh the intellectual components" (Malcolm 2008, p. 238).

That definition comes from 1978, from the first edition of Guttmann's book. It is probably the reason why sport was saturated there with autotelic qualities characteristic for the then and earlier times, for Coubertin and his followers. They negated professional sport treated in a utilitarian, instrumental way - that is, as a means for other non-sport aims.

Malcolm presents also McPherson and his co-authors' interpretation of sport. They distinguish the four most important qualities in it. A significant criterion enabling the evaluation of how advanced a given sport is and 
By the way, currently the term "sport" is understood only in such a way in the United States. It does not refer to any other form of practical activity (Pfister 2007). On the other hand, the term "physical culture" is not well-known there nowadays (sic!) and it generally is not used there, unlike in Canada, Great Britain, France, Germany, Norway and other Scandinavian states, countries of Central and Eastern Europe and in the former Soviet Union and today's Russia.

what its level of competences and its level of structuration are. A proper structure (formal assumptions) is significant for sport even in its informal forms. It is necessary, for example, for children's street or backyard football, or for playing baseball in a park. In those and in other cases the course of the game is determined by some rules which are known and accepted by its participants. That type of sport has a low level of formal structure. A higher level of structuration is characteristic, for example, for the Football World Cup. Its preparation and course are strictly controlled by great bureaucratic sport and non-sporting institutions, which are established, among other things, to do that on the basis of rigorous rules which have been accepted earlier.

The second significant quality of sport is the fact that it is goal-oriented on variously understood success. It depends on criteria which - similarly to the criteria for failure - are usually clearly defined.

The third characteristic feature of sport is rivalry between particular athletes or teams, whereas the fourth quality is, in their opinion, its ludic character. They maintain that sport is ludic, which implies - according to them - that sport includes also qualities characteristic for play and game. They justify it in an etymological way, because the term "ludic" comes from the Latin "ludus", which means play or game. Summing up, it can be proclaimed that sport, according to McPherson and his co-authors, is a structured, competitive form of game, which is teleologically oriented on success.

In the abovementioned definitions it is possible to notice cultural messages which are implicitly rooted in them. It is confirmed by N. Elias and E. Dunning (1986), who point out that contemporary sport refers to patterns of competitive physical activities, which appeared in Britain and Ireland in the $17^{\text {th }}$ and the $18^{\text {th }}$ centuries. It is also possible to point to different understanding of similarities and differences between play, game and sport. For example, G. Tomc discusses these notions referring to B. Suits and K. V. Meier's viewpoint and presenting - in opposition to them - his own understanding of these terms. He proclaims that "For Bernard Suits, sport may or may not be play (if it is involuntary or extrinsically motivated, it is in his opinion not play) may or may not be game (he distinguishes sport games in which rules are the crux of the matter, like soccer; from sport performances, in which ideals are essential and to be approximated, like gymnastics). For Klaus V. Meier sports may or may not be play (as in Suits) but are necessarily games (they require physical skill by participants pursuing the goal of the game), although all games are not sports (for example chess or poker)" (Tomc 2008, p. 9).

Then Tomc - considering qualities of play, game and sport, and then relations between them, taking into account performances, rituals and experimentaion, comes to the conclusion that there are:

- games (in which parallel world of pretence is created by players trying to approximate an ideal skill, for example a physical skill in sport),

- performances (in which a parallel word of pretence is created by players trying to approximate an ideal representation of life, for example an aesthetical production),

- rituals (in which a parallel world of pretence is created by players trying to approximate ideal behavior for example an aesthetical production) and

- experimentation (in which a parallel world of pretence is created by players trying to approximate ideal classification of the world, for example scientific research.

It follows from our theoretical perspective that

1. All sports are either games or performances,

2. All games and performances are not sport,

3. But all games and performances are forms of playing." (Tomc 2008, p. 9).

I present two quotations - and not their discussion - because Tomc presents Suits and Meier's viewpoints - as well as his own - in a highly essential way. Hence their synthetic interpretation could deform their content. What is significant in that case are also original expressions. By the way, such a type of formal solution is permissible also in notes or stage directions constituting marginal currents of considerations in their relation towards the central statement.

Treating Tomc's considerations as the context for an analysis of S. R. Kretchmar's views included in the paper presented during the conference of the International Association for the Philosophy of Sport in Seattle (August 2009), entitled "Do Games Require Artificial Problems That are Neither Too Hard Nor Too Easy?", it is possible to notice that reservations about Suits' conception presented by the outstanding Slovenian sociologist can be referred - to some degree - to the paper of the American philosopher of sport. 


\section{MacFadden - physical culture and scientism}

The term "physical culture" was used as early as the end of the $19^{\text {th }}$ and the beginning of the $20^{\text {th }}$ century, but mainly in the USA. It is assumed that it was introduced in the United States by Bernard MacFadden, who was a body-builder by vocation, an expert in principles of healthy nutrition and a proponent of natural methods of healing. This is proved by "Physical Culture", which he published since 1899 (Piątkowska 2006, p. 83, www.bernarrmacfadden.com). Popularization of the term in the USA and other English-speaking countries was especially contributed to by the extensive - and often reissued - 5-volume "MacFadden's Encyclopedia of Physical Culture (by MacFadden assisted by Specialist in the Application of Natural Methods of Healing)", which had naturalist, biological and medical character. I refer here to its seventh issue, which was published in New York by Hammond Press W. B. Conkey Company Chicago in 1926 (the first issue comes from 1911). The presentation of problems connected - according to MacFadden - with physical culture which is included in the "Encyclopedia" influenced many issues which later on and traditionally were associated with that term, because MacFadden, over 2915 pages of his "Encyclopedia", included in the field of reflection on manifestations and qualities of physical culture (today we would say: in the field of physical culture sciences) everything which the popular and the medical viewpoint associated with that term then. This refers to issues connected with maintaining health, causes of illnesses and anatomy (vol. 1), with nutrition, diet, individual and team training as such, and with women's training. MacFadden characterized also dance (vol. 2) as an art and a form of exercise and fitness, vocal culture, beauty and activities aimed at highlighting and maintaining it, medical tests on an empty stomach, biomechanical medical tests, hydrotherapy, medical qualities of fasting, principles of first aid in danger and after accidents, painkillers and medicines for chronic ailments (vol. 3), illnesses and their general traits and symptoms (vol. 4), reproduction and development of the human being, physiological foundations of sexuality and marriage, the female reproductive system, women's illnesses, pregnancy and childhood, the baby's health and proper birth, the male reproductive organs, the male reproductive system disorders, masculinity and fatherhood (vol. 5, MacFadden 1926). MacFadden, the initiator and the editor of that great encyclopedic undertaking, dedicated to physical culture - understood as a manifestation of activity constituting an aim in itself, of aims, aspirations and results of strictly cultural qualities - not much place as a matter of fact. He focused his attention mainly on creating a medical, physiological, biological and, more widely, a natural scientific context of justification connected with physical activity of the human organism, as well as on the then innovative considerations in the field of theory of sport. Admittedly MacFadden paid some attention to dance, vocalism and care for beauty, but he did not consider those issues - as well as others - in the context of culture studies, as the term "physical culture" requires.

Issues, views, hypotheses and theories which were attributed to the notion of physical culture reflected a scientific character of the then scholars - and especially of the viewpoint of the second half of the $19^{\text {th }}$ century and the beginning of the $20^{\text {th }}$. Natural sciences - as the only manifestation and guarantor of scientific rationality and valuable cognition - and their supposed almost unlimited possibilities were apotheosized then, and the significance of the humanities and of social sciences (including philosophy and newly appeared psychology and sociology) was diminished on the basis of materialism, and also treated as anti-philosophy (Kołakowski 2000, p. 19), evolutionism, naturalism, positivism and, especially, scientism (Pearson 2004, Cameron 1979), which was an extreme current of positivism. The humanities and social sciences were treated as non-scientific and metaphysical, and it was proclaimed that they could only have some significance for scientific knowledge if they become similar to natural sciences (By the way, mathematics - according to scientism - had only an auxiliary value in its relation to natural sciences). That highly simplified view was promoted by, among others, A. Bain, K. Pearson and F. Engels. It was also proclaimed on these grounds - too optimistically - that with the help of specialized sciences of empirical orientation, and especially of natural ones, the basic cognitive problems will be completely solved (Kołakowski 2000, p. 18). 
Proponents of the scientific world view created - similarly to MacFadden and his followers contexts of justification of physical activity from the area of widely understood sport on the basis of medicine and sciences constituting its foundations - especially those connected with human biology. Physicians and natural scientists were those who justified positive influence of physical activity of autotelic qualities on the individual's development and health, on stimulation and proper course of physiological processes, on basal metabolism, development of the bone, joint and muscular structure (in other words: the motor, biomechanical system), the vascular system, the lymphatic system, the neural system, the hormonal system, the sexual system, etc. It was attempted, in a way which was innovative then, to make people participate in sport - that is, physical education, physical recreation and amateur, highly competitive and even professional sport. The innovative character of those attempts consisted of referring to the newest achievements of medicine, human biology and related sciences, as well as to principles of nutrition, dietetics and, especially, to natural ways of healing and supporting the human organism while explaining that autotelic movement activity from the field of physical culture (understood in the present-day way). Into the field of interest were also introduced those issues which have strictly cultural - that is, non-biological - character: dance, something which would today be called vocalism, cosmetology and other activities aimed at maintenance and enrichment of bodily beauty.

The abovementioned scientific interpretation lacked a general methodological perspective concerning classification of types of sciences. Hence there was no awareness of qualities of disciplines constituting physical culture sciences and definitions of their content-related and formal ranges. This led to chaos in the field of interest of science studies and to confusion between various types of sciences which - from the viewpoint of general methodology and specialized methodologies - have different foundations; disciplines which in the content-related and methodological sense are included in the present day physical culture sciences.

This initiated a cognitive dissonance concerning the following questions: a) does culture studies contain natural sciences with the included biological sciences? b) or are they disciplines subordinated to natural science and biology? c) or are culture studies and natural sciences - including biological sciences (which also concern medicine: illness and health) - autonomous towards each other? It was and still is - a problem which is difficult to solve, although not for methodological and content-related reasons, but because the problem seems to be easy in that respect: it is easy to prove that culture studies are not natural sciences and that physical culture sciences deal with those non-artistic, cultural forms of movement which have autotelic, axiological and symbolic character.

Medical - and, more generally, biological sciences; and even more generally, natural sciences constitute, shortly speaking, foundations for research connected with functions of the organism and its physical effort, with its changes, development, temporary and lasting dysfunctions.

The difficulty consists of the fact that MacFadden's conception of physical culture - and, especially, of connected specialized disciplines - has become established in research and teaching institutions dealing with education of PE teachers, coaches, physiotherapists, specialists in the fields of tourism and recreation and physical culture managers of various ranks. It has become established among university graduates who are active in the fields they have been educated in and who are often employed in autonomous research institutions and tertiary education. What is especially important in that respect is quantitative growth and qualitative development of teaching and research personnel in units, departments or institutes of natural scientific provenance. The abovementioned workers are those who especially contribute to consolidation of the myth about superiority of natural sciences in perception of phenomena from the field of physical culture - what is understandable taking into account MacFadden's tradition. That myth is also supported by persons connected with the theory of sport (theory and practice of particular sports), who are predominately interested in biotechnological research effects supporting the human (and not only human) organism in its striving for sports success. 
Admittedly MacFadden - and his followers - called autotelic physical activity physical culture, but he referred almost the whole context of justification to natural sciences, human biology and medicine (this happened - as I have already partly mentioned above - because of the scientific research fashion which was obligatory then because of the third positivism (in other words: neopositivism, the Vienna Circle, scientific empiricism, logical empiricism) coming into being into the 1920s. It avoided humane, social - and hence cultural - theoretical background. Admittedly the term "physical culture" includes a cultural element, but in spite of that the notion was treated in a way. There were attempts to make cognitive reflection concerning it similar to natural science.

For example movement rehabilitation - in other words, physiotherapy - could be easily placed in such (that is, understood in MacFadden's way) physical culture, whereas some "orthodox" representatives of sports sciences refrained from placing it in the field of sciences which are connected with it. They did so because they were (and perhaps still are) of the opinion that the discussed rehabilitation, similarly to tourism and movement recreation, goes beyond the identity of sports sciences and has no connection with highly competitive sport. Sport-for-all is not sport for them but movement recreation, while tourism is a manifestation of economical activity which - according to the abovementioned orthodox researchers - should be placed in the area of interest of universities and disciplines dealing with the discussed activities.

Extending that digression, it can be added that physiotherapy (movement rehabilitation), although it belongs to MacFadden's conception of physical culture, cannot be included - from the viewpoint of culture studies, of traditional and contemporary reflection on culture - in the realm of culture as understood in a symbolical, axiological and autotelic way. It belongs neither to the humanities, nor to social sciences, because it is rooted in medicine, biological sciences, natural sciences. It can be placed as a major element in those research/teaching institutions where, in accordance with their tradition, there are departments considering movement, physical effort, its physiological symptoms in the light of biology, medicine or natural sciences. Moreover physiotherapy as a major, content-related and formal basis of a university institute or department, strengthens considerably the status of a given university within the tertiary education system regarding teaching, research and structural issues, or in the field of competition between universities.

Coming back to the main current of considerations, it is worth emphasizing that the cognitive aim of scientism had a too reductionist character and scientism quickly became marginalized in the realm of philosophy. In the case of neopositivism, the rejection of that current was contributed to by the very founders of the Vienna Circle, with R. Carnap as the leader. They came to the conclusion that limitation of the conception of science and of the connected research to natural sciences, physicalism, mathematics and logic (Reinchenbach 1936) was an obvious mistake.

MacFadden's fundamentalism supported by scientism and the third positivism - in spite of their spectacular philosophical (that is, strictly cognitive) failure - exerted, and (in spite of lack of contentrelated justification) still does exert considerable influence on reception of phenomena and the vision of physical culture sciences, especially among representatives of biological sciences.

\section{Scientism and scepticism concerning natural sciences}

Rejection of scientism and the discussed form of positivism as a source of theoretical inspiration of statements about qualities of physical culture and the connected sciences was mainly contributed to by development of gnoseological scepticism, especially that referring to natural sciences, which took place in the $20^{\text {th }}$ century. After a mass, materialistic and positivistic (especially in the form of scientific empiricism) attack on cognitive values of the humanities (in other words: of social sciences; By the way, I treat economy as a social science, but as a science which is not included in the humanities), there appeared a strong current which was firmly rooted in the philosophy of science, general methodology and science studies, and which negated necessity and universality (as Kant would call it) - that is, indisputability - of research achievements of natural sciences. The humanities 
were attributed with metaphysical qualities - that is, qualities abstracting from sensations, and hence supposedly "unworthy" of knowledge on reality - that is, of nature -although some of them (or some their significant areas) had no intention of referring to nature. Natural sciences were, on the other hand, accused - and that accusation have not been withdrawn - of unreliability and impossibility of giving an account of nature and, consequentially, of explaining and understanding what it is, cognition of its real organic and non-organic properties. It however turned out that anti-inductionist criticism of cognition based on empirical sensations (which makes them different from introspective experiences) aroused not only humility towards potentials of research aposteriorism, but also highlighted the fact that its result is, as a matter of fact, pure metaphysics - that is, such statements about physical beings which admittedly refer to them, but which do not really present (describe, explain) their real state. Hence it is difficult to settle when we get to know something real about nature - that is, when we get to know the so-called truth about the being. Nowadays natural sciences are in a sense like symptomatic medicine. Some manifestations of some reasons are perceived, sensually experienced by us, but after all there is nothing sure to be told about the source and qualities of those reasons. What is proclaimed by us is solely pure metaphysics. Hence making natural sciences the main content-related and methodological foundation of statements about cultural phenomena, including those about physical culture, seems also to be a misunderstanding.

At the beginning of the $20^{\text {th }}$ century a reference to assumptions of the forgotten $18^{\text {th }}$ century anti-inductionism took place. Once it was proclaimed by D. Hume (1947, 1963, 1974), who - on the grounds of his radical empiricism - challenged sensual experience as a method leading to certain knowledge. He supported in that respect, among others, ancient sceptics, including representatives of the Platonic Academy who were criticized by Aurelius Augustine.

Hume maintained that there is nothing certain to be told about the natural world on the basis of senses. Empirical research is not sufficient in that respect. Neither statements about particular cause and effect relations, nor about substance in general and particular substances, nor about forces influencing them are empirical statements. According to Hume, they are only a priori statements (that is, such which are independent of experience), which only seemingly refer to empirical knowledge (Hume 1947, pp. 67-77). There is nothing certain to be told about empirical reception of matter, because sensual cognition takes place within the human subject. It does not go beyond the subject. The human being refers only to sensual data which come into being in his receptors. Hence there is nothing sure he can ascertain about stimuli or material sources of those stimuli. He takes a stance only on his own sensations - not on the external world, because subjective sensations are something different than objective qualities of the external material world, of nature. Moreover - as a matter of fact - the subject, according to Hume, does not proclaim his opinions on the basis of sensual data, but only on the basis of ideas which come into being in his mind and which are only abstract copies of those data (so they are not the same thing as sensations). They are associated on the basis of inborn associative skills which are typical for the human mind and have cause and effect, spatial and temporal character. This is the basis on which the human being creates his images, views, opinions, representations concerning the material world on. However he can never find out to what a degree those internal subjective representations are in accordance with the perceived reality or if they are in accordance with it at all. There are no criteria for this. Moreover, the subjective image of the external world, of nature, is something different than material nature.

At the beginning of the $20^{\text {th }}$ century L. Nelson - the founder of the Goettingen School - which, besides the Badenian School and the Marburg School, was the third neo-Kantian current (Nelson 1994, Leonard Nelson in der diskussion 1994, Kosiewicz 1995, pp. 301-303) - aroused justified pessimism referring also to empirical natural sciences (called - after I. Kant $\{1971,1984,1986\}-$ aposterioric sciences, as well as inductive science - that is, those based on empirical knowledge).

Thus Nelson's criticism of the theory of cognition follows a beaten agnostic track marked out by ancient skeptics and he somehow confirms on his way the sensibility of Hume's criticism concerning truthfulness of cognition and possibility of building a theory of cognition - that is, 
sensibility of criticism based, among others, on anti-inductionism. The Berlin philosopher, by referring to traditional gnoseological scepticism, creates - by consolidating negation of or scepticism about possibility of any sensible method and theory of cognition - solid foundations for various forms of contemporary methodological and epistemological anarchism. If cognition (as episteme) is impossible to be justified with a theory of cognition (epistemology), you should agree with Feyerabend's anything goes - with his total anarchism presented in "Against the Method" (Feyerabend 1970) and in other works.

What is, however, important, is not so much the abovementioned conclusion from Nelson's epistemological research, but the way leading to it, arguments, the context of justification. His thought is original and innovative taking into account the age of his activity, whereas beyond the historical perspective, from the present day viewpoint, after L. Fleck (who expressed doubt in epistemological value of the notion of objective reality which is to be independent from experience, and of the empirically defined scientific fact, which is treated as an objective event or objective state of affairs), after K. Popper, T. Kuhn, I. Lakatos, P. Feyerabend, it is not significant for philosophy anymore. Too late it was rescued from oblivion. Nevertheless, it is impossible to question its greatness.

Nelson points out that epistemology proclaiming necessity of building a theory of cognition is impossible for three basic reasons: 1. It cannot justify objective validity and truthfulness of cognition anyhow, 2. It is a mistake to assume a necessity of justification of cognition in general and of any particular cognition; 3. An assumption concerning necessity of justification is logically contradictory and contrary to psychological facts (Nelson 1994, pp. 143-145).

Thus Nelson assumes in his theory of cognition - in an preemptive and a priori way - an assumption negating a possibility of its creation. He introduces into the theory of cognition a new level of agnosticism - including agnosticism concerning natural sciences. He does not negate, however, cognition as such, because possibility of cognition is the basic and irreducible fact (and what is a problem is not the possibility of cognition but rather the possibility of a mistake - of false cognition), but he questions the validity of its justification. If no justification of cognition is valid and objective, the very cognition is neither valid, nor objective, because it is impossible to create any proper and reliable criteria of cognition - like, among others, criteria of absolute and non-relative truthfulness - or any sensible conventionalism which would resist falsification for some time, which means time significant from the viewpoint of building and functioning of a smaller or a greater cognitive paradigm. For that reason all cognition is doubtful.

Nelson widens Hume's agnosticism - which points to the inadequacy of cognition (because of subjective immanentism) in its relation to the perceived external world - with the impossibility of building a proper justifying theory. Hence he not only widens that agnosticism, he also strengthens it. He does not attack objectivity of the very cognition directly, but he negates its validity and thus challenges not so much the sense but rather the possibility of building proper research procedures, assumptions, methodological criteria which would allow the assumption that cognition is certain. Thus he constructs a negation of cognition in a different way than traditional skeptics - he does not refer to the very episteme (he does not question its cognitive qualities at once), but he only points out that it is impossible to justify its validity. If it is impossible to create any certain foundations for epistemology, this means that very cognition as the certain, basic, irreducible fact (for example in the form of Descartes's cogito) cannot take place. Hence such a standpoint leads to radical and universal agnosticism challenging the possibility of cognition (including cognition based on sensual, empirical perception).

Gnoseological doubt about empiricism of natural sciences is characteristic also for P. Duhem (1904, 1906) and H. Poincare's $(1908,1911)$ conventionalism. The latter became the most famous in the field of conventionalism. He assumed - shortly speaking - that while considering material reality (this refers also to formal sciences and the humanities) we work on theoretical and methodological assumptions which were made earlier or we introduce new assumptions based on the principle of a 
social agreement - in other words: of a convention - characteristic for scientists' milieu. Effects of that research also have qualities of a convention, if they are in conformity with the established conventions. Those conventions are sometimes utterly transformed, they are subject to a scientific revolution and they are replaced by new ones. Conceptions and theories describing and explaining the sensual world are - from the viewpoint of conventionalism - so far from and, simultaneously, so close to empirical reality, as opinions about nature in Hume's anti-inductionism.

T. Kuhn (1968) maintains in his paradigmatic or anti-accumulativist theory of scientific revolutions that science - including natural sciences - develop within assumed, smaller or greater paradigms, which have a smaller or a greater historical range (like, for example, the whole age or of a revivalist crisis), a smaller or a greater content-related range of research (like, for example, characteristic for all Renaissance sciences or focusing only on the Copernican revolution). The paradigm includes hypotheses, laws, theories and sciences, and the connected methodological assumptions from the fields of specialized methodologies and general methodology. Kuhn is of the opinion that the whole scientific knowledge - including all natural sciences (or solely natural sciences, or only their part) - sometimes undergoes complete breakdown and rejection. After that, building and development of knowledge on sensual reality begins until the moment of exhaustion of intellectual resources and of developmental potential of a given paradigm. Cognitive value of natural sciences is strictly connected with theoretical and methodological conventions characteristic for a given paradigm. Its basic property is changeability and relativity of findings of empirical natural sciences. From the viewpoint of anti-accumulativism, natural sciences never lead to certain and final knowledge.

I. Lakatos $(1990,1995)$ admittedly confirms Kuhn's cognitive conclusions, but he says that scientific revolutions rarely take place. Changeability concerning contents and methods takes place in a gradual way. A radical and complete break with previous opinions seldom takes place. There is a correspondence in the field of selected research problems and issues, categories and notions. Admittedly there appear new solutions, but the previous ones are defended against radical rejection by a hard core and a protective zone composed of hypotheses which can be changed while maintaining primary assumptions included in the hard core of a theory which is an element of a given natural science. This does not mean, however, that values included in hard cores of scientific theories are lasting and final. Introducing a conception of a hard core of a theory and of a protective zone made of hypotheses is to warn against creation of a science without reliable content-related and methodological foundations, against creation of $a d$ hoc hypotheses as well as registering laws and theories referring to them. Just such (too often) manifestations of activity on the grounds of natural sciences must be falsified as quickly as possible. This does not mean, however, that the rest of manifestations of activity in the field of natural sciences must provide with certain knowledge. By the way, it is possible to see that Lakatos modifies Poppers and Kuhn's views in his works in the field of the philosophy of natural sciences to a considerable degree.

Methodological anarchism, according to P. Feyerabend's interpretation (1970, 1979), also challenges cognitive abilities of both past and present natural sciences. This refers to specialized methodologies of all sciences. Feyerabend proclaims utter chaos and anarchism in that respect. It is the reason why statements characteristic for art, literature, religion or from the field of common sense knowledge have the same cognitive value. Hence natural sciences - similarly to the whole science and sources of knowledge of other kinds - are unreliable.

Feyerabend's views should be taken note of as one of the possible standpoints, but they should also be rejected as too radical, because, against Feyerabend, I am of the opinion that methodologies based on assumptions of formal sciences (logic and mathematics) are not a proof of complete cognitive anarchism and nihilism. I think, however, that - in spite of reliable formal foundations they can lead to deepening of ignorance about real qualities of nature around us and of the cosmos. They can do it mainly because of continuous changeability of assumptions, principles, instruments characteristic for methodologies of various specialized sciences (Kosiewicz 1996). Results achieved 
thanks to their application can be temporarily recognised, they can generate and increase social prestige. However, they do not lead to (and probably will never lead to) final research findings, scientific laws and theories. Those results are changeable, relative and ostensible in the cognitive sense because of theoretical and methodological conventions which are approved here and now and which are the starting point for empirical research. Regarding that issue, I am of the opinion that specialized methodologies - their application - do not bring us closer to a reliable view of reality, to cognizing it such as it is. Taking that into account, it can be assumed that specialized methodologies of natural sciences, similarly to general methodology (which is referred to by them) are both a form and a manifestation of agnosticism. They contribute to ostensible creation of certain knowledge, of apparently reliable ideography and nomotetism; they camouflage ignorance. They are engaged in covering and apparent uncovering of that which anyway will never be cognized - explained and understood - by natural sciences.

Retreat from scientism was strengthened by self-negation of the Vienna Circle's physicalist assumptions, and with anti-inductionism, hypothetism, fallibilism, anti-accumulativism, methodological anarchism and agnosticism. Natural sciences became a proof of deepening scepticism - that is, of a crisis concerning cognition and the theory of cognition (the distinction inspired by Kant's distinction between episteme and epistemology. The conception supporting the need of looking for a theoretical and methodological background for physical culture sciences on the basis of the humanities and social sciences had been challenged for decades. Finally, a qualitative jump, which $\mathrm{K}$. Lorenz calls fulguration, happened, since it turned out that - contrary to earlier assumptions - the main theoretical foundation of physical culture sciences are culture studies and their axiological background.

The fact that the term "physical culture", including the world "culture", has been adopted had numerous implications when the fashion for scientism and positivism - and, especially, scientific empiricism - had passed. A reorientation - that is, retreat from MacFadden's conception of physical culture, which was indirectly based on Carnap's naturalistic-empiricist reductionism, took place on the grounds of physical culture sciences. There was a turn towards many-sidedness and multidimensionality of research, which treated cognitive values of inquiries from the field of the humanities, social sciences and culture studies - that is, those which were described by scienticism and neo-positivism as metaphysically-based research - with special attention. It was universally concluded that no assumption from the field of methodology and of axiology as a philosophical discipline could legitimize any evaluation of science on the grounds of science studies, any creation of any hierarchy of scientific disciplines. Specialised methodologies cannot be reduced to any common gnoseological denominator which would include universal categories constituting a basis for objective claims concerning a higher or a lower position of particular sciences in their possible hierarchy. Such a denominator - that is, such a basis - cannot be created even by general methodology, because it is autonomous in its relation towards specialized methodologies, which are partly mediated by it.

\section{The notion of physical culture in Poland and other European countries}

\section{Polish understanding of physical culture in the context of Eastern European systemic transformation}

A considerable role in shaping physical culture was played in Poland by J. Piłsudski - a leader of the national liberation movement and the most outstanding figure of pre-war Poland. In 1914 - to emphasise specific qualities of methods of shaping soldiers' fitness - he introduced the term "physical culture", which he used also later (Hądzelek, Rotkiewicz, Chełmecki, Dorcz, Dudek 1998, p. 16, 2009, pp. 5-6). He wanted "the issue of physical culture and strength of the young generation to be solved by general educational work” (ibid., Wieroński 1937, p. 91).

It seems to me that Piłsudski used the discussed term rather rarely (Marszałek Józef Piłsudski ... 1998, Piłsudski 1999, Józef Pitsudski protektor... 2005). This is proved by his numerous written 
statements. The greatest attention is paid by him to physical education and sport there. They all have an occasional, trite, official, not very deep and demanding character. The term "physical culture" appeared there only in a common-sense context and without a definition which could explain its meaning. Neither was it synonymous with the term "physical education". It results from the abovementioned quotation that then Piłsudski and others could understand physical culture as an effect of some unspecified "educational work" as such - that is, of physical education in the context of other forms of school and extra-school education. The name was not considered from the viewpoint of culture studies. Nevertheless, it was popularized in pre-war Poland.

Probably Piłsudski became acquainted with the term "physical culture" as early as in London, where at the end of the $19^{\text {th }}$ and beginning of the $20^{\text {th }}$ century the abovementioned magazine of MacFadden's, "Physical Culture", was accessible. Application of that term was surely contributed by "MacFadden's Encyclopedia...", which was popular in English-speaking countries.

In 1929 Piłsudski created the Central Institute of Physical Education in Warsaw - an institution of military character - which in 1936, after the death of the founder, was named after him. In 1929, just after the institute was opened, it started to be called the Polish university of physical culture ("Przegląd Sportowy" 1929, p. 3).

Since 1937 the magazine "Wychowanie Fizyczne" /"Physical Education"/ - deriving its origin from "Ruch" /"Movement"/ magazine - had the subtitle "A Monthly Magazine Dedicated to Physical Culture Issues". "Ruch" emphasized the need to develop the body and "Wychowanie Fizyczne" started to emphasise the notion of physical culture in the theoretical and practical sense (Demel 2006, pp. 1- 3). In the period between the World Wars there was also founded the "Kultura Fizyczna" /"Physical Culture"/ publishing house, which published 3 magazines: "Sport Polski" /"Polish Sport"/, "Sport Szkolny" /"School Sport" and "Wychowanie Fizyczne" /"Physical Education"/. Since 1937 until the outbreak of World War II it was led by W. Humen (Hądzelek 2006, p. 9).

The notion of physical culture became popular in the area of the abovementioned Western European Countries. After the 1917 October Revolution it was popularized in Germany by Arbeiter Turn und Sportbewegung - that is, by the Workers' Gymnastic-Sports Movement (Piątkowska 2006). The term "physical culture" was also assimilated by Russia and the Soviet Union in the form of the term fizkultura (fizitcheskaya kultura). This is proved by the first handbook in the field of physical culture published in the Soviet Union in 1925 (Dupperon 1925). After World War II the term was accepted by the Soviet Union's satellite countries ${ }^{3}$. It was saturated with ideological traits aimed at

\footnotetext{
${ }^{3}$ Establishment of theories of physical culture in the countries of Eastern Europe was especially strongly influenced by conceptions born in the Soviet Union. L.P. Matvyeyeff distinguished three stages of establishment of that field. The first stage took place - in his opinion - in the period between the $1920 \mathrm{~s}$ and the 1940s, the second between the 1940s and the 1960s and the third in the 1970s and the 1980s. The discussed author described that theory in a laconic way as a unification of the theory of physical education and the theory of sport. Simultaneously he understood it, being less or more aware of it, in pedagogical and praxeological terms. It refers to education and teaching people and improving athletes' qualifications.

Matvyeyeff (as well as other Soviet theoreticians), while discussing phenomena from the field of physical culture, treats sports issues separately, because he writes about "physical culture and sport" and treats sport as an autonomous phenomenon. On the other hand, when he discusses the notion of the theory of physical culture, he includes the theory of sport - as a phenomenon which is integrally connected with physical culture and which is associated by him with physical education - into its field of interest. He proclaimed also that the theory of physical culture "is an integrated system of knowledge about the essence of physical culture (...) and, first of all, of knowledge about development and social formation of personality, as well as concerning the optimal development of human vital forces in the system of educational factors" (Matvyeyeff 1984, p. 22). The issues of the theory of sport, which concern formation of personality, human vital forces, improvement of health, are also included into the field of interest of the theory of physical culture in the discussed Matvyeyeff's definition (although he does not declare it openly).
}

Matvyeyeff, by emphasising the significance and need of development of the human individual's various traits and qualities, of his/her self-realisation and self-affirmation in the socialist system, tried to draw attention to autotelic character of physical culture. He treated neither it, nor the human being as a means for ideological aims (Matvyeyeff 1980, 1983). 
consolidation of the socialist system. In that role of a propaganda instrument it, unfortunately, also appeared in science (Godlewski 2005). However, after political transformations it became a purely cognitive and practical category in Poland and it meant something different than in its Soviet interpretation. Namely, the term "physical culture", aside from many other elements, included also highly competitive (professional, Olympic, spectacular) sport, while in the Soviet interpretation the

Another viewpoint on the role and function of physical culture was presented by J. Merhautowa and P. Joachimstaler from Czechoslovakia. They treated physical culture and its theory mainly in an instrumental way, as a means to class and political ends connected with the political system of the state. This is a significant difference, because it points out that development of the theory of physical education in Czechoslovakia did not take place according to the abovementioned authors' declaration. They highlighted the pioneering character and the leading role of Soviet ideology - as well as the considerably analogical character of the process of formation and development of the theory of physical education in the Soviet Union and in Czechoslovakia.

Differently to in the case of the prototype, they put special stress on the necessity of consolidation of ideological and political functions of physical culture as a realm influencing systemic foundations of the state. Matvyeyeff, on the other hand, wrote about autotelic qualities of physical culture, about the need for the individual's development and improvement by the means of physical culture - which was to be systemically connected with socialism - and of a theory which refers to it. However, a demand of that kind could not be realized in a totalitarian state (Kosiewicz 1986, p. 109).

The Czechoslovakian authors described the discussed discipline as "a synthetic, scientific theory of physical culture", created on the basis of theoretical and methodological principles of scientific materialism. They treated physical culture as an overall social system characterised by a unity of ideological, scientific and methodological, programme-related, normative and organizational foundations of physical culture and sports activity of the population of the whole country (Merhautowa, Joachimstaler 1984, Kosiewicz 1986, p. 109).

In a similar way the discussed field was presented also by theoreticians from the German Democratic Republic. They described the theory of physical culture as "the Marxist-Leninist theory of socialist physical culture". They proclaimed that it had developed in the GDR on the basis of "collected philosophical and theoretical, historical and sociological materials and making significant use of scientific achievements of the Soviet Union and other socialist countries" (Sieger, Neidhard 1984, Kosiewicz 1986, pp. 109-110).

W. Sieger and H. Neidhard understood the discussed theory as, for example, "a complex system of knowledge about the essence of physical culture as such, and about the essence of more important factors and regularities in development of socialist physical culture, which is organically connected with the socialist vision of life".

By the way, Czechoslovakian authors - J. Merhautowa, F. Joachimstaler, W. Cechak - also perceived the influence of Western European philosophical and sociological conceptions on the theory of physical culture. They were of the opinion that - because of the abovementioned influence - it is possible to distinguish at least three groups of conceptions of the discussed theory.

The first group was to be constituted by existentialist and phenomenological interpretations, which treat physical culture as "flippant" activity aimed mainly at play. It especially refers - in their opinion - to such authors as C. Lenkaj, A. Jughen and J. Loy (Kosiewicz 1986, p.113).

The second group of conceptions was to be connected with the so-called "compensation theory". Their authors according to the Czechoslovakian theoreticians - treated development of physical culture as development of a specific substitute mechanism which facilitates adjustment to demands of contemporary civilization and technology - that is, to phenomena which clearly outdistance slow evolution of natural environment and the human organism. There appeared in those conceptions views of a naturalistic character which especially emphasise the human being's biological nature and his connection with environment, which were proclaimed by K. Lorenz and H. Plessner.

Another set of conceptions refers to assumptions of the Frankfurt School, whose founders paid attention to "technocratic" and "manipulative" functions of the state in the process of development of society. For example, S. Güldenpfenning highlighted ideological and political aspects of physical culture and maintained that they should be treated as manifestations of a specific realm of politics and researched by means of appropriate theoretical and methodological instruments characteristic for political science (J. Merhautowa, F. Joachimstaler, W. Cechak 1984, Kosiewicz 1986, p.114).

The views of the Czechoslovakian theoreticians of physical culture prove the existence of a particular cognitive duality and of a strong dependence on the internal totalitarian system and the connected state ideology. On the one hand, they glorified - as a result of political compulsion - non-scientific Marxist ideological assumptions on the grounds of the theory of physical education, which mainly supported maintaining power by the communist government. On the other hand, they perceived free development of philosophy and sociology in the West, and their influence on various manifestations of culture - including physical culture. They had, however, to criticize it as a phenomenon proving real political entanglement (in contrast to that what they allegedly experienced in their own country), arguing untruthfully that Western scientific achievements are a proof of false consciousness. 
abovementioned notion of sport had been placed outside physical culture, because sport was treated as a special phenomenon which was made different from other forms of physical activity by its spectacular character. Sport was treated as a special phenomenon which is made different from other forms of physical activity by its popularity, interest from the mass media and the electronic media (Kosiewicz 2005).

In the countries of Central and Eastern Europe - and especially in Poland - ideological traits of the notion of physical culture have been neutralized, rejected. The stress - similarly to earlier and later elsewhere - has been placed on its essential foundation, the factual context of justification of its qualities. The fact that terms such as culture, theatre, cinema, religion, society, politics or sport and physical culture were used by propaganda in the Soviet Union, and that during its existence they were saturated with negative qualities - which meant that my colleagues from Central and Eastern Europe associate them with ideological compulsion and political oppression - does not mean that they have lost objective values attributed to them and that they should be removed from the cognitive discourse as is demanded in the case of the term "physical culture".

In Polish literature, apart from the behavioural ${ }^{4}$, relational-subjective ${ }^{5}$, axiological ${ }^{6}$ and holistic $^{7}$ interpretation of the notion of "physical culture", there is also found an additive definition - that is, by

\begin{abstract}
${ }^{4}$ Z. Krawczyk formulated an evaluating definition of physical culture, which presents - after Antonina Kłoskowska - and anthropological and cultural, sociocentric and behavioural viewpoint.

Namely, he maintains that "Physical culture is a relatively integrated and established system of behaviours in the field of care of physical development, movement fitness, health, bodily beauty, human physical perfection and expression, which take place according to patterns which are obligatory in a given community, as well as results of those behaviours". The author, in the commentary about the content of the abovementioned expression, also draws attention to aesthetic values, "supernormal" fitness and expression of the human body which is released and developed by highly competitive sport, and mainly by spectacular sports. The abovementioned definition of culture is close to assumptions of sociobehaviourism which - referring a priori to inborn inclinations and interests of the educated - pay little attention to their analysis and treat success of acculturation, socialization and education as dependent mainly on introduction of the individual into a definite socio-cultural environment.
\end{abstract}

That definition is, however - in my opinion - too reductionist. It does not take into account - because of the source of inspiration and the assumed viewpoint - spiritual values cooperating in creation of manifestations of physical (not only bodily, but also material) culture. Neither does it take into account its influence as a factor giving a chance of versatile personnel development, unlike the currently dominating model, which focused mainly on intellectual improvement.

${ }^{5}$ The psychobehavioural character of Krawczyk's definition neutralizes in a sense A. Wohl's statement of relational-personalistic, secular and, simulataneously, Marxist character. He proclaims that physical culture cooperates in creation of spiritual values, that it interweaves both with spiritual culture and with material (bodily) culture in the closest way, and that the development of physical culture is aimed at versatile formation of the human personality in the existing conditions of social life, which have been created by the entirety of social relations. In the final fragment of the last sentence Wohl refers to one of the theses on Feuerbach by K. Marx. He turns attention to social relations, which play a significant role in formation of the personality and of culture (including physical culture). Their significance during formation of mental health and the personality is especially emphasised by culturalists from the fields of neo-psychoanalysis and humanistic psychiatry - and especially E. Fromm, who came from the Frankfurt School and was one of its co-founders. He emphasised their significance in an orthodox Marxist way.

${ }^{6}$ According to Maciej Demel - a pedagogue, a physician, outstanding theoretician of physical education, the author of the Polish version of health-oriented education and the pedagogy of health "Physical culture includes all those values which are connected with the human physical form and physical functioning, both according to his own subjective experience and according to the socially objectivised perception. Those values - to say it in the most general way - refer to health, the body build and posture, immunity, function, fitness, beauty. Analogously to other cultural values, they have dynamic character and they shape human views and attitudes" (Demel 1972, p. 72). He creates a definition characterized by an axiological orientation, which is oriented on cultural - not biological - values.

${ }^{7}$ According to the interpretation proposed by me (that is, the author of the presented text), physical culture constitutes a set of forms of social consciousness which function in praxis of the society - forms which integrate and consolidate the union between knowledge (and patterns), on the one hand, and behaviours (and their results), on the other. They constitute a basis for harmonious development of versatile, mature personality and health in the physical, mental and relational (that is, social) dimension. This is about development, where a special place is 
enumeration of its main components. In that case it is supposed to include highly competitive sport, mass sport, sport-for-all, amateur sport, school sport, sport of the disabled, physical education, games and plays, movement recreation, highly competitive tourism, pilgrimage tourism and recreational forms of tourism.

In Scandinavian countries the notion "physical culture" did not have - and does not have - any ideological context connected with political conditions (Breivik 2009, pp. 313-314, Faarlund 1993, Kvaløy Soetereng 1993). Similarly to in the United States and other English-speaking countries before World War II, it has been used in a cognitive meaning. A similar viewpoint is presented also by $\mathrm{H}$. Eichberg (1998, 2004, 2009), who is popularising the notion of "body culture" nowadays. It has a similar content to the notion of "somatic culture", which was promoted and rejected in Poland several years ago ${ }^{8}$.

occupied not only by spiritual values, but also by care, projection and the connected, dynamic and directed process of transformations aimed at the human being's physical perfection - that is, among others, the body build, posture and aesthetics, fitness, function and physical immunity. Physical culture, according to that interpretation, is not only a set of forms and symbols existing in social consciousness and in particular individuals' psyches, but also material facts, like - for example - sports facilities and the connected architecture of places destined for sports games (like in ancient Olympia), which are interpreted in the light of axiology, cultural and symbolic values.

Thus physical culture is the entirety of mankind's or of some society's achievements in the ideal, the material and the relational sphere - achievements created in general historical development or in a given age, and which in a given environment - are both means and results of physical culture and personal culture of individuals belonging to that environment.

Those achievements - speaking in the most general way - are a set of existential facts constituting internal and external reality; that is, all understandings of those facts and expressions of those understandings in various artistic (like e.g. literary ones, plastic ones, architectonical ones), philosophical, scientific, technical, technological versions, as well as in a form of social institutions, such as the Olympic movement, federations, ministries, clubs, etc. Physical culture also includes material creations of strictly utilitarian character which are necessary for participation in its various forms - that is, necessary for interpretation of activity in its field in axionormative, symbolic terms. It refers, among others, to various objects, such as equipment which is necessary for sport for all, highly competitive sport, tourism or physical education. Physical culture is created by all the abovementioned elements, which are socially created, processed, adopted and handed over.

The basis for the above holistic conception of physical culture is constituted by a synthesis of J. Kmita and Antonina Kłoskowska's theories of culture, and elaborating premises which underlie Z. Krawczyk, M. Demel and A. Wohl's definitions of physical culture. In the accepted interpretation the behavioural viewpoint, which is characteristic for Kłoskowska's sociological definition of culture, has been widened. In contrast to Kmita's theory, attention has also been paid to material - and not only to mental - determinants of culture. That understanding of physical culture also takes into account the significance of messages of personalistic character recommending care of development and improvement of personality. It brings it closer to the demands of the axiologically and holistically understood theory of physical culture according to its normative interpretation and to the ideals characteristic for education in physical culture as a practical discipline, as well as to philosophical and pedagogical sources from the sphere of reflection belonging to pedagogy of culture. It also pays attention to the world of values implying some activities depending on norms or patterns, the world prone to influence of subjective criteria of values, which are externalized and shaped in relations subject - object and subject subject.

${ }^{8}$ The term "somatic culture" (in other words: bodily culture) was promoted in the field of physical culture sciences by Z. Krawczyk, who treated it as synonymous with the term "physical culture" and used both terms interchangeably. Popularisation of that viewpoint has been especially contributed to by A. Pawłucki and Z. Dziubiński. The latter applies Krawczyk's conception as a theoretical and research instrument replacing only the term "physical culture" with "somatic culture". I think that using the expression somatic (bodily) culture, originating from the word "soma", as synonymous with the term "physical culture" is somehow inadvisable, because those notions have - as I suppose - different ranges of meaning which only partly overlap with each other. For example, physical culture does not include such bodily phenomena as: intestinal movement activity (peristalsis), physiology, the vascular system, the lymphatic system, the urinary system or the neural system movement activities - that is, those phenomena which have purely biological - and not cultural - qualities in the genetic, organic, structural and functional sense. Thus the notion of "somatic culture" goes beyond a purely cultural range of problems. From that viewpoint the notion of somatic culture is somehow internally contradictory, because culture excludes non-cultural biological phenomena which are independent from it. It can 
For example in Norway or in Germany, in spite of the fact that significance of physical culture is perceived and defined there, the terms "sport" and "sport sciences" are consistently used on the grounds of science and academic teaching. It is proved, among others, by the names of the local universities dealing with the discussed fields of activities, such as e.g. the Norwegian School of Sport Sciences in Oslo and the Deutsche Sporthochschule in Cologne.

\section{Multiform character of the notion of sport}

In many Western European countries there is applied - although not always consistently and not always on the basis of the same definitions - a division of sport in general into highly competitive (Olympic, amateur, professional) sport and sport for all. In Polish literature it is also possible to find different interpretations of that issue.

L.O. Amusa from the Centre for Biokinetics, Recreation and Sport Science of the University of Venda (Thohoyandou in South Africa) distinguishes three levels of sports activity. Amusa refers to mass sport (that is - in his opinion - sport for all), amateur sport and professional sport (that is, highly competitive sport) (Amusa 2009).

The first of them - that is, mass sport - is treated by the African author as synonymous with sport for all. It is also identified by him with popular sport understood as common sport. The term refers to physical activity of various, more or less fit groups, strata or social classes.

Amateur sport - according to Amusa - is a proof of love of sport and its praise. It is based on the assumption that that type of sport is a good of anthropological-social character, that it exerts a positive influence, that it shapes and develops the human body, that influences social relations and the individual's socialization in a positive and desirable way. A significant element of the abovementioned praise is the fact that no material gain is "associated with "true amateur sports" (Amusa 2009, p. 4,

refer to them, but culture is something different than nature - such as it is suggested and justified by Krawczyk in his book "Natura, kultura, sport" /"Nature, culture, sport"/.

Somatic culture - according to the interpretation of Dziubiński, who refers to Krawczyk and Pawłucki - is a system of behaviours in the field of care of physical development, movement fitness, human health and physical perfection. This is an interpretation which is reductionistic in that sense that it does not include non-bodily spheres of human activity in the field of physical culture. It refers, among other things, to the artistic, the material and the institutional sphere. Thus the definition of somatic culture and the definition of physical culture have a common content-related field of interests concerning the abovementioned kinds of behaviours. What makes them different - taking into account the abovementioned interpretation - are mainly the following issues: a) the fact that somatic culture is more focused on purely biological human nature, b) the fact that physical culture deals not only with care of physical development etc., but also with the other abovementioned manifestations of human activity in a given field. They are regarded in symbolic and axiological terms and not in medical, biological or naturalistic, as it was in MacFadden's case.

The notion of bodily culture, or body culture, is systematically popularised by H. Eichberg, a political scientist, a sociologist of culture and a sociologist of body culture of German descent, living in Germany and currently working at the University of Southern Denmark in Odense. That notion is close to the notion of somatic culture. However, it includes not only mistakes characteristic for the notion of somatic culture, but it also introduces into its range other qualities going beyond the content connected with the term "physical culture". The point is that body culture refers also to fitness and symbolic values concerning artistic skills and qualities which are characteristic for such arts as pantomime, circus acrobatics, ballet and dance (treated as an aesthetic phenomenon characteristic for performances of folk bands). A proponent of the category of body culture also has to take into account tattooing, which is practised for, among others, ritual-religious reasons, military reasons, penitentiary reasons (when tattoos emphasize e.g. an individual's level of initiation and place in social gradation), strictly aesthetic reasons (when they are to beautify and make the human bodily image attractive) and strictly artistic reasons (when a tattoo is not only a cultural fact, but also an artwork). He must also deal with activities in the fields of cosmetology and plastic surgery, which beautify the human body. Taking that into account, I come to the conclusion that the sense, content and meaning of the notion of body culture go significantly beyond the notions of physical culture and of widely understood sport. Hence both the possible notion of somatic culture sciences and the possible notion of body culture sciences should not be treated as synonymous with physical culture sciences or sport sciences, since the first notions are irrelevant to physical culture or sport. 
105), that it has autotelic - and not instrumental - qualities. Hence he points out - something I do not agree with - that material goods connected with sports activity are not very valuable.

Professional sport, on the other hand, is described by the African theoretician as such a form of activity which squeezes primarily playful activity into the format of sport as earning a living. Expectations which are connected with it require a high level of professionalisation aimed at success in rivalry (Amusa 2009, pp. 4-5).

A similar division into professional sport, highly competitive amateur sport (like basketball matches of the USA university league, which is independent from the National Basketball Association, but which provides it with athletes) and recreation sport was presented (independently from Amusa) by M. McNamee and A. Bloodworth (2009, pp. 18-19) during the conference of the British Philosophy of Sport Association in Dundee. McNamee and Bloodworth's standpoint is generally well-founded, although it requires some refinement to make it more reliable.

The division of sport which is proposed by them is acceptable - it does not inspire any essential reservations ${ }^{9}$. It seems, however, that any form of authentic amateur sport can be included to sport for all.

The last sentence - because of the verb "can" which it includes - informs, however, about some doubt connected with the problem if it is possible always and everywhere, in every particular case to apply the general quantifier to the discussed form of sport. It refers, among others, to the abovementioned university basketball league, because that form of sport can be also treated as sport which does not have a completely amateur character, but which certainly - in spite of a high level of competences - is not fully professional yet. That form of sport can be also described as highly competitive amateurism to make it distinct from professional sport, which is a highly competitive activity by nature. Amateur sport, on the other hand, usually is not a highly competitive phenomenon.

There is, however, a special manifestation of amateur sport which can be regarded as a nonauthentic - that is, deformed, faked - one. It is sport which was, as a matter of fact, a masked form of professional sport. It was an axiologically deformed, hybrid form of sport, which ideologically united contradictory values and assumptions and which was promoted in the socialist countries, where it was impossible from the viewpoint of the existing laws to practice sport as a profession. Hence that amateur sport practised on the highest level was, as a matter of fact, camouflaged professional sport. Athletes were fictitiously employed in the police, army, offices, state-owned companies, steel mills or mines. They got permanent wages, grants and bonuses. Instead of doing work connected with their employment - based on other alleged professional qualifications - they participated in training and training camps, as well as in various matches, games and championships. For example, allegedly amateur Soviet ice-hockey national teams defeated the Canada and the USA teams composed of the most outstanding professionals of the time. Allegedly amateur teams and representatives of other socialist countries won in the World, European and other continental championships. Surprisingly, this remained in accordance with the ideology of the then version of Olympism. After World War II it was accepted and supported by all the IOC's chairmen who had to deal with that phenomenon - including Avry Brandige and Antonio Samarancha. By the way, the latter contributed to awarding Moscow (1980) and Beijing (2008) organization of the controversial Olympic Games.

Taking into account the fact that the abovementioned athletes were not obliged by contracts or legal regulations characteristic for professional sport, they could not be regarded - from the viewpoint of administrative law - as professionals in the formal sense. The sport they dealt with was - from the viewpoint of the abovementioned law - not fully professional sport. In spite of that, regarding their skills, they were the equals of champion professional athletes and teams, or even surpassed them.

\footnotetext{
${ }^{9}$ In the abstract of M. McNamee's and A. Bloodworth's conference paper there is no fragment concerning the division of sport which is proposed by them.
} 
To conclude, it can be proclaimed that - independently from professional and not fully professional sport - sport for all includes both high-level amateur sport (which sometimes is not fully amateur sport) and low-level amateur sport. In that sense it is related to, or - a possibility preferred by me as the author of the paper - includes mass sport and common sport.

In the times of the People's Republic of Poland (before 1989) the government and the Communist Party authorities aspired to make sport (or, in other words, physical culture) a mass phenomenon. It was a highly positive aim. The content of mass sport - that is, fitness-related and health-related aims - would be described from the present-day viewpoint as typical for sport for all. Since the socialist countries were very poor, their governments lacked financial means and other resources (personnel, competences, facilities) for realization of that important - for culture, civilization, fitness and health - undertaking. Hence acts of abuse and perversion took place.

This - and not the idea of popularisation of physical culture of recreational character - was also the main reason why promotion of mass sport was given up both in the theoretical and the practical dimension. The terms "social masses" - and, especially, "mass sport" - sometimes aroused almost allergic reactions, negative associations with the political context of reification of the individual and of the so-called social masses, and of instrumentalisation of mass sport. However, the abovementioned terms - with the connected notions and theoretical constructions of strictly cognitive character should be regarded independently from current, more or less negative sentiments and associations connected with a temporary political context. A term, a category or a notion connected with mass character and referred to sport or culture (mass culture) should not have any non-cognitive, emotive assumptions and contexts of justification. Otherwise we also have to deal with ideologisation, moralisation and promotion of definite political assumptions on the ground of scientific research. This is the way - as I suppose - mass sport is treated by Maciej Demel. For him it is synonymous with "mass physical culture". That mass character does not arouse any negative associations in the discussed author. For Demel it means universal (bold face introduced by me) hygienisation of life, a school of character, health and fitness, because the arsenal of its means goes beyond sport and even beyond movement exercises (Demel 1972, p. 72). As we can see, the notion of mass sport means for Demel the same as the notion of common sport.

L.O. Asmusa, on the other hand, who is free of associations and experiences concerning the socialist ideology, understands mass sport as synonymous with sport for all. He also identifies both terms with popular sport, understood also as common sport.

By the way, in the sociology of culture there is the commonly used term "mass culture". Monographs about it could fill whole libraries. Nobody has hit upon an idea to postpone the word "mass" which is included in it, whereas, for example, in Poland - because of negative political and ideological sentiments - the term "mass sport" (and especially the word "mass") are marginalized and replaced with the term "common sport". By the way, from the present-day viewpoint mass sport similarly to common sport - can be described (although it is not necessary) as a typical form and one of the manifestations of sport for all.

In Norway the term mass sport is commonly used. It was discussed by, among others, Gunard Breivik (2009a) during a plenary session of the $14^{\text {th }}$ Annual Congress of the European College of Sport Science (Oslo, 24-27 June 2009). He pointed out that it is the opposite of elite sport, and that mass sport is connected with, among others, "jogging, hiking, eastern martial arts, fitness and lifestyle sport" (Breivik 2009, p. 543) - that is, with movement recreation, which is known also as sport for all.

Common sport can be understood in at least five ways.

Firstly, the term concerns popularisation of sport in every form - both in the theoretical and the practical sense. It refers to, inter alia, professional sport and sport for all, active sport and passive sport. 
Secondly, the term "common sport" concerns popularisation of various particular sports in urban and rural environment, among adults and the old, among children and youth in primary, secondary and tertiary schools and with the help of extra-school educational and non-educational institutions, in clubs, community centres, in the army, etc.

Thirdly, the term "common sport" can be treated as synonymous with sport for all. The state and the connected institutions and organisations should aspire for such popularization of sport to make it accessible for all, regardless age, sex, the level of physical and mental fitness, social background and financial resources (Kosiewicz 2006, pp. 9-11).

The fourth interpretation, referring to the abovementioned Demel's opinion, points out that the term "common sport" can be understood as synonymous with the term "mass sport".

The fifth interpretation proclaims that if we assume - similarly to in the fourth interpretation that the terms "common sport" and "mass sport" are (taking into account the abovementioned Breivik's viewpoint) synonymous, then we can proclaim that common sport is the opposite of elite sport.

The last - that is, the sixth interpretation - has the least particular character. It is a manifestation (it refers to Amusa) of an extended viewpoint pointing out that the term "common sport" can be treated as synonymous with the terms "mass sport", "sport for all" and "popular sport".

\section{Relations between the notions of sport and physical culture}

In some recent work (monographs, collective works, papers) and public statements I maintained that sport as such can be divided into highly competitive (spectacular, professional, Olympic) sport and sport for all. The latter includes all other forms of sport of autotelic character, that is such as the abovementioned lowly competitive forms of sport as well as other manifestations of activity from the field of physical recreation - such as e.g. active movement relaxation in the form of games and plays, hiking, fishing, mushroom picking, recreational forms of tourism - which in many cases are not connected with any form of rivalry. I was of the opinion that the abovementioned categories of sport that is, highly competitive sport and sport for all - create a unity which can be also called physical culture.

Nowadays, in contrast with the abovementioned outdated viewpoint, I assume (for the first time) that the notion of sport (including the notions of professional sspectacular, highly competitive, Olympic $\}$ sport and the notion of sport for all, and the connected notion of sport sciences, cannot be synonymous with the notion of physical culture and the connected notion of physical culture sciences, because the cited pairs of notions have different ranges of meaning.

The notion of sport (and hence the notion of sport sciences) does not include that field of activity which can be called physiotherapy (or movement rehabilitation). It concerns that part of a given physiotherapy which is mainly focused on restoration of lost, regressed, deformed fitness with the help of forms of movement which are worked out by specialists and adapted to various limitations.

Neither the realm of the abovementioned sport (and of the connected sciences) include, among others, various and sublime forms of massage (excluding sports massage). This also refers to tattooing applied, among other reasons, for: a) utilitarian reasons - for example, for military reasons to scare off the enemy, as in the case of the Maoris, the New Zealand aboriginal people, b) in order to emphasise a different subcultural identity of individuals in prisons, criminals at large, sports fans, hooligans - as well as social stratification in their groups, c) for aesthetic reasons concerning beautification of the body.

Neither of the abovementioned notions (and of the connected sciences) include issues referring to bodily paintings, cosmetology and cosmetics or plastic surgery operations taking into account bodily needs of archaic warriors, athletes, fans, persons striving for the optimal aesthetic effect and patients. 
A part of the abovementioned phenomena and activities of strictly cultural character (and placed beyond sport) - this refers to the highlighted range of physiotherapy and massage - is included in physical culture, whereas all of them - those attributed to physical culture and those which are not attributed to it - belong to a wider notion of body culture and to the connected cognitive reflection.

From among the three abovementioned notions (sport, physical culture, body culture) the one with the narrowest range is the notion of sport together with sport sciences. A notion wider than that is the notion of physical culture and the connected notion of physical culture sciences, which includes apart from various forms of sport - also the abovementioned manifestations of movement therapy or non-medical, non-erotic forms of massage. The notion of body culture (and cognitive reflection referring to it) goes well beyond the range of the notion of sport (and sport sciences) and the notion of physical culture (and physical culture sciences). It includes all sport and non-sporting phenomena, activities, theories and forms of scientific and non-scientific reflection referring to culturally determined aspects of the human body. It is such a wide notion that issues concerning physical culture (and sport, which is connected with it) which are placed in it undergo considerable marginalisation in it and lose their autonomy to a considerable degree. Taking into account limitations concerning the notion of sport (and of the connected sciences) as well as difficulties concerning defining the notion of body culture - as well as the vague and ambiguous character of the notion and of the researched subject of body culture (Eichberg 2009), it seems that the most suitable - from the identity-related and cultural viewpoint - for a package of issues characterized in that paper and the concerning field of research seems to be the notion of physical culture (and of the connected sciences).

It results from the above considerations that the notions of body culture (and of its counterpart: somatic culture), of the physical culture and sport can be variously defined in autonomous, mutually overlapping and coinciding ways. Relations taking place between them are, however, ambiguous. They arouse constant interest and will provoke argument between both theoreticians and practitioners of sport or physical culture. That phenomenon - that is, never-ending defining of ranges of terms, categories or notions - is characteristic for the humanities, for culture studies.

In some European countries there are also applied equivalents of the notions which are discussed above and in the endnotes. It refers to the science of man in motion, human motion sciences, exercise sciences, physical activity sciences, sciences of physical education, antropokinetics, homokinetisc, kinesiology (Bouchard 1976, pp. 10-21), gimnology kinanthropomotorics, physical movement activity, cultural human movement (Ronson 2009), bewegungskultur (that is, movement culture) (Grössing 1993) or kinanthropology (Jirásek 2005). They focus their attention on the notion of movement and on scientific reflection referring to it. They all have numerous good points justifying their application as well as bad points. Hence they have their proponents and opponents, similarly to those whom I have paid greater attention. Considering it in a detailed way could only confirm this to a greater or a smaller degree. It would not help to decide definitely which of all the abovementioned terms (and others which have not been mentioned) - and notions which are referred to - is the most suitable. This also applies to possible new terms, which can deepen and widen knowledge in the field of the discussed issues and phenomena, turn attention to their new aspects or inspire new viewpoints. It will contribute, however, to terminological pluralism.

I am, however, of the opinion that the most suitable category, term, notion describing the area of research which is characterized in the paper is physical culture. It is not - as the term and the notion free of flaws, similarly to the other pointed out or possible new terms referring to the complex and complicated set of theoretical and practical issues, which are impossible to be included by one relevant name, category or term. The notion of physical culture constitutes, however - in my opinion - the most central and suitable name, which is rooted in the tradition of the discussed issues from the end of the $19^{\text {th }}$ and the first decades of the $20^{\text {th }}$ centuries. It emphasises in the most accurate way cultural qualities of various forms of sport, of forms of physical activity which are close to them and of the connected cognitive reflection. 
Even when it is assumed that no consistent distinction is made between the notion of sport, the notion of physical culture, the notion of body culture and other abovementioned terms, it does not mean that juxtaposing such terms with each other is a proof of content-related negligence. For example, there are overlapping terms in titles of many magazines, such as "Physical Culture and Sport. Studies and Research" (Kosiewicz 2008), "Kultura i Społeczeństwo" ("Culture and Society), "Wychowanie Fizyczne i Sport" ("Physical Education and Sport") or "Philosophy, Ethics and Sport".

It is commonly known that culture is a function, an effect of social activities; that physical education, including elements of sport (sport - and especially school sport - should also pay attention to children's and youth's education), is their core element. On the other hand, ethics, which is a significant part of culture and education (including also physical activity), is also understood as one of main branches of philosophy, similarly as aesthetics and axiolology.

The last of them constitutes - from the viewpoint of philosophy - the basis, the source, the sense and the essence of all aspects of cultural evaluation.

The abovementioned mutually overlapping and merging notions found in physical culture sciences are characterized by elasticity taking into account various terminological options, theories and contexts of justification. Such elasticity is typical for the humanities (and the humanities are, after all, the basis for culture studies). The abovementioned variety enables permanent exploration deepening, modification and creation of new (more or less valuable) original viewpoints, hypotheses, theories and even of separate disciplines, branches and sciences - which are not, however, emancipated from knowledge concerning physical culture.

\section{Do natural sciences include physical culture sciences?}

Can physical culture science be treated as natural sciences? Can they be placed in the field of disciplines connected with health science of medical character? Can they be regarded and evaluated mainly from the viewpoint of biological sciences and - in a wider perspective - from the viewpoint of natural sciences?

Unfortunately these sciences could be - and, as has turned out on the basis of the latest decision by the Ministry of Science and University Education, they can again be - regarded from that viewpoint. It is an enforced practice of many-years standing, which is obviously contradictory with assumptions and principles of general methodology and specialized methodologies, and which, paradoxically, is applied in Poland in all schools connected - to varying degrees - with widely understood physical culture, as well as in the Ministry of Science and University Education.

In Poland there is a surprising formal and functional ambivalence concerning the discussed notions - that is, physical culture and sport. On the grounds of science the notion of physical culture is more emphasized than the notion of sport, because in the field of health sciences there is distinguished an area called physical culture sciences. Admittedly - referring to foreign (including Englishlanguage) literature - the term "sport sciences" is also more and more often used in Poland, but the latter notion has not achieved, however, such a formal status as the notion of physical culture sciences.

On the other hand, in the functional sense - concerning public administration - the current situation is different, because the notion of sport has been more emphasised in the government's practice than the notion of physical culture for many years. That notion - because of the range of their practical interests - was taken into account in the names of such ministries as, for example, the Ministry of Sport, the Ministry of Education and Sport and the Ministry of Sport and Tourism. By the way, earlier - that is, before 1989 - there were ministries which had physical culture in their names. Nowadays, however, it is the notion of sport and practical activity connected with sport which are emphasized on the administrative level. In my opinion, this is an unnatural move, because even in that case we are dealing with physical culture where various forms of sport are included. That culture is 
popularised with the help of various forms of highly competitive, amateur, common, school and mass sport, with sport for all or with highly competitive as well as recreational forms of tourism.

A trend which is found in many Western countries points out that a unification can take place (although it is not necessary), and that not only the ministry of sport, but sports sciences (as a synonym of physical culture sciences) will be formally and officially sanctioned. Admittedly the name will be changed, but the content, sense and range of the researched problems will not be changed, because they will concern the abovementioned widely understood physical culture. Sport is a cultural phenomenon. Hence I suggest maintaining the notion which openly emphasises cultural character of the discussed field of research - namely, the notion of physical culture sciences. Nowadays, however, there is a duality in the government, because in the ministry dealing with science the notion of physical culture is emphasised, and in the ministry connected with organisation and management of the discussed physical activity the notion of sport is emphasised. It is not known whether that dualism is going to disappear and how that formal and content-related problem will be resolved.

A particular dichotomy - however, of another kind - appears in English-language literature, which is popularised also in the region of South East Asia and the Pacific. It concerns sports science and sports studies. The first notion refers to research activities in the field of sport sciences, and the second is connected with education - that is, with university studies, subjects which are learned and passed by students. They include significant elements of what D. Malcolm calls sport sciences. Sports studies are based on a curriculum referring especially to handbooks, which first of all constitute introduction into generalised, popularized (that is, simplified) effects of many-years' and varied research. Regardless of that interpretation, sports studies can be also understood as studies of (that is, research on) sport and their (theoretical) effects ${ }^{10}$, similarly to - to some degree - sports philosophy, sports sociology or sports psychology (Malcolm 2008, p. XII, Coakley and Dunning 2000, Dunning 2002, pp. 211- 238, Gratton and Taylor 2000).

Both with their current and with their possible future names the abovementioned branches of knowledge and teaching are certainly included - in my opinion - in the field of culture studies; that is, of the humanities, which are treated in that text as a synonym for social sciences. A possible modification of their names would change nothing in that respect. They are not health sciences in the medical sense. Neither they are biological, nor natural sciences. They should not be included by them. For that reason, regardless of the abovementioned trend, I am inclined to suggest another form of unification - namely, reverting to such names of ministries which include physical culture. It would correspond - in a strict and unambiguous way - with the notion of physical culture sciences.

Culture studies deal with such issues which go beyond nature. By the way, according to what L. Feuerbach proclaims about theology, everything in the field of the humanities is a creation - is rooted in man's abilities. He writes that "the real content of theology is anthropology, that there is no difference between predicatives of the divine and the human being, and - what is a consequence between the divine subject and the human being; that they are identical, because everywhere where as it happens in theology - predicatives express not accidental qualities, features, but the essence of a subject, there is no difference between the subject and the predicative, and the predicative can be put in place of the subject" (Feuerbach 1959, p. 24). If theology, according to that interpretation, is treated

\footnotetext{
${ }^{10}$ By the way, there can appear some disputable comments or interpretations referring both to the notion of studies and to the notion of research, and concerning their ranges as well as mutual relations.

Namely, proponents of empirical - and, especially, natural, sciences are of the opinion that, unlike those in the humanities, their inquiries are just typical research, whereas the term "studies" - also in their opinion - is reserved solely for the humanities of strictly theoretical character, like philosophy, history, non-empirical sociology, psychology or pedagogy.

On the other hand, representatives of the humanities think that their exploratory activities can be called both "studies" and "research", because - regardless of the name and from the viewpoint of general methodology they conduct theoretical research typical for those disciplines, which often, although not necessarily, has empirical character and which can be correctly called both of the abovementioned names.
} 
as anthropology, that means that culture is also the fruit of activity, of anthropological reflection. That case refers, of course, to the philosophy of religion and to philosophical anthropology of one of the first German critics of Hegel's views - to considerations on human qualities and abilities which are not rooted in biological (or natural) sciences, but in the humanities. According to that interpretation, both culture and theology (which is a significant part of culture) are - from the viewpoint of the final and the most significant cause - an effect of supernatural, mental (rational, emotive and volitional) qualities of the human being, which are subject neither to content-related, nor to methodological judgments from the viewpoint of assumptions of natural sciences.

It is obvious that the basis for the human subject's cultural activity is his physical, bodily, natural background. It does not result from that, however, that cognitive reflection concerning human cultural activity can be included in natural sciences. Similarly (or in a supplementing, specifying way), it can be remarked that the final condition for human activity in the field of formal sciences (from the viewpoint of psychologism, and not of anti-psychologism or, for example, idealistic realism) is - as it was mentioned above - his physical, bodily, natural existence. It does not imply the conclusion that the discussed sciences (like, for example, mathematics) can be included in natural sciences. Neither does it justify the conclusion that final determinants of creativity or other forms of cultural activity (and mathematics) should be looked for by means of, for example, genetic research.

$\mathrm{K}$. Fasting is of the opinion that culture has been often strongly influenced by the human being's biological conditions. It refers also to manifestations of physical culture, such as "participation in leisure time activities and sport". They depend not only on social determinants, but also on age, sex, race or disability (Fasting 2009, p. 108). It does not mean, however, that the sources of culture should be looked for in nature, that they are biologically or genetically determined, as in assumptions of Freud's psychoanalysis. By the way, his view pointing to culture as a source of suffering - the view that organically determined libidinal energy is the only and primary source of culture - has been rejected (Freud 1967, 1975, 1982, 1995). Biological factors only influence various forms of culture but do not create it. It comes into being in social relations and it influences them. It influences also symbolic and axiocreative perception, as well as establishment of human corporeality, manifestations of sexuality, forms of physical activity.

Biological sciences connected with the human being are traditionally - after MacFadden, among others - counted among physical culture sciences. Because of the bodily foundations of human physical activity, they perform - shortly speaking - a significant cognitive function: they describe natural foundations of particular forms of movement. In spite of the fact that knowledge in that respect is extremely important for multiform human activity in the field of physical culture, it is not knowledge of cultural character. From the formal (that is, institutional) viewpoint it is strictly connected with culture studies, but it has separate methodological and theoretical assumptions. Knowledge of that type is focused on the human organism and not on effects of mental, axiocreative, symbolic activity of the human being entangled in social relations. It includes auxiliary data which support practical - that is, in that case, physical, bodily - activity. Its reception of axiological (ethical and aesthetical), social (philosophical, sociological, pedagogical, historical \{universal or strictly defined - referring e.g. to art and literature with the connected theories\} or political) character is dealt with by the humanities (in other words: social sciences) constituting an immanent and the fundamental - and hence the most important - part of culture studies. Putting stress on alleged superiority and the dominating role of natural (biological in that case) sciences within physical culture sciences and the connected marginalization of the humanities - which constitute, after all, a necessary and hence an unquestionable foundation for culture studies, their essence and objectivisation - is, euphemistically speaking, a clear shortcoming in the field of science studies.

The abovementioned exaltation and aspirations for superiority, as well as deepening and more and more aggressive marginalization of the humanities (understood in that paper as a synonym for social sciences) in the field of physical culture sciences may lead to the separation of biological sciences. 
Its result can be, among others, the foundation of some department, institute or unit which would be separate from universities of physical education existing in Poland. Thus that more or less academic (or non-academic) institution could be called, for example, the institute of biological determinants of physical effort (or, more shortly, the institute of biology of effort). Physiology dealing with sport is commonly called the physiology of sport. Representatives of biological sciences dealing with sport proclaim that there is not distinguished such a notion as the physiology of sport as a specific sub-discipline in physiology as such. What is distinguished is only the physiology of effort which shortly speaking - focuses its attention on research into the human organism before, during and after effort. The organism of the human being - similarly to of other living creatures - is in its internal connections, mediations and entanglements [not only from L. von Bertalanffy's viewpoint (1973)] only a purely biological, non-cultural functional structure, which does not generate any values by itself.

In the formal and content-related sense the title of the magazine from the so-called Philadelphian List - "Biology of Sport" - which has a so-called impact factor - can be treated similarly to the notion of the physiology of sport. In its title there are included both a content-related and a formal mistake. Sport is a cultural - and not an organic - phenomenon. Hence it is not subject to biological research. Biology (that is, its representatives) can research effort which is connected with it all organic elements accompanying it, but it can never research cultural relations. Biology (or, according to a wider interpretation, natural sciences) has no relevant research instrument to do it.

Sport as a cultural phenomenon should not be regarded from the perspective of biological cognitive instruments, because sport is considered first of all (in the fundamental, necessary and unconditional way) from the viewpoint of values which are attributed to some conventionalised behaviours based on principles, regulations, rules and norms, which are objectively (e.g. physically) measurable, discretionary (aesthetical, ethical) and take into account many more various axionormative themes - and which are not results of the physiological-structural way of functioning of the human subject. What matters in cultural reflection (in the field of physical culture) concerning sports activity is not movement as such - as a purely physical phenomenon - but only such a form of movement which has been attributed with conventionalised social values of symbolic and autotelic character.

Concluding considerations on the abovementioned magazine, it can be stated that - in my opinion - it could be entitled "Sport and Biology of Effort". Such a title would highlight the autonomy of the notions and a possible narrow range of their overlapping cognitive inquiries, which would be connected solely with biological analysis, description and explanation of specific kinds of movement - that is, those forms of movement which are characteristic for particular sports. The proposed title would not refer, on the other hand, to sport on the whole - that is, sport according to its holistic cultural interpretation. By the way, "sport as such" is only a notion, it is an abstract being. There exist only particular sports, particular forms of sports activity.

Moreover, it should be emphasized - in accordance with assumptions of epistemology, axiology, general methodology and specialized methodologies, science studies, the philosophy of science, the philosophy of empirical sciences and the philosophy of nature - that there are no values in nature. This can be attributed to it during ideography or a nomotetic move, what is an obvious methodological mistake. Attributing nature with values was called "a naturalist fallacy" by D. Hume. It is a fallacy which had been unconsciously made until his times (and which was also made later, when his views were forgotten for some time - that is, until the $20^{\text {th }}$ century) by philosophers and other representatives of science. Description and explanation of researched reality should be objective - that is, free of emotive qualities, autotelic and instrumental ones, to such a degree as it is possible (Hume 1963, Hołówka 1981).

Taking into account the abovementioned considerations, it can be added that all biological sciences dealing with issues connected with the human organism (such as anatomy, biophysics, 
biochemistry or biomechanics) are, in the methodological and the content-related sense, in a similar situation to the discussed physiology of effort - they do not consider the human being in the abovementioned categories of values, from the viewpoint of axiology.

Because of the fact that biological sciences are placed outside culture studies, they are not and they cannot be characteristic, typical representatives of those studies. This also applies to their place in physical culture sciences. They perform in those sciences only an auxiliary, supporting function - in a similar way (although not in the same sense) as, for example, a team of technical workers of various trades in their relation to artists of a theatre.

Admittedly in big theatres (for example, in Teatr Wielki in Warsaw) the number of those technical workers can be greater than the number of artists, but that does not mean that they should have teleological, qualitative and functional superiority, that artistic aspirations should be subordinated to tasks and aims of other professional groups. There is the opposite situation in that case. The artists actors, singers, dancers, musicians, theatre directors, choreographers and stage designers - are those who decide in a given institution about its artistic character. Other, non-artistic workers should support realisation of their plans and put them into practice because they are employed in order to support art and not to subordinate it to other non-artistic aims.

\section{REFERENCES}

Amusa L. O. (2009) Towards a Social Philosophy of Achievement in Sport. International Journal of Eastern Sports \& Physical Education, 1(7).

Bertalanffy von, L. (1973). General System Theory. New York: George Braziller.

Breivig, K. (2009a). Can Sport Became Ecologically Sound? In S. Loland, K. Bo, K. Fasting, J. Halen, Y. Ommundsen, G. Roberts, E. Tsolakidis (Eds.), Sport Sciences: Nature, Nurture and Culture. Oslo: Gamlebyen Grafiske AS.

Breivig, K. (2009b). Friluftsliv and Outdoor Education - the Deep Ecological Approach. In S. Loland, K. Bo, K. Fasting, J. Halen, Y. Ommundsen, G. Roberts, E. Tsolakidis (Eds.), Sport Sciences: Nature, Nurture and Culture. Oslo: Gamlebyen Grafiske AS.

Bouchard, C. (1976). The Physical Activity Sciences: A Basic Concept for the Organization of the Discipline and the Profession. International Journal of Physical Education, 3.

Cameron, I. (1979). Scientific Images and Their Social Uses. An Introduction to the Concept of Science. London: Butterworth.

Coakley, J., Dunning, E. (2000). Handbook of Sport Studies. London: Sage.

Demel, M. (1972). System wychowania fizycznego w szkole polskiej. Krytyka i propozycje modelowe /System of Physical Education in Polish School. Criticism and Model Propositions/. In W. Adamski, S. Drążdżewski, Z. Krawczyk (Eds.) Stan obecny i zatozenia dalszego rozwoju kultury fizycznej /The Present-Day State of Physical Culture and Assumptions for Its Further Development/. Warszawa: AWF.

Demel, M. (2006). 100 lat - Od „Ruchu” do „Kultury Fizycznej”/100 Years - from “Movement” to "Physical Culture". Kultura Fizyczna, 1-2.

Dudek, D. (Ed.) (2005). Józef Pitsudski protektor polskiego sportu /Józef Pitsudski as the Protector of Polish Sport/. Warszawa: Agencja Reklamowo-Wydawnicza A. Grzegorczyk.

Duhem, P. (1904). Ewolucja mechaniki /Evolution of Mechanics/. Warszawa.

Duhem, P. (1906). La theorie phisuque, son objet et sa structure. Paris.

Dunning, E. (2002). Figurational Contributions to the Sociological Study of Sport. In J. Maguire, K. Yung (Eds.), Theory, Sport \& Society. London: Jai.

Dupperon, G. A. (1925). Teoriya fizitcheskoy kultury. Moskwa.

Eichberg, H. (1998). Body Culture. Essays on Sport, Space and Identity. London: Routledge.

Eichberg, H. (2004). The People of Democracy. Understanding Self-Determination on the Basis of Body and Movement. Arhus: Klim.

Eichberg, H. (2009). Body Culture. In S. W. Pope \& J. Nauright (Eds.), The Routlege Companion to Sport History. London: Routledge.

Elias, N., Dunning, E. (1986). Quest for Excitement: Sport and Leisure in the Civilizing Process. Oxford: Basil Blackwell. 
Faarlund, N. (1993). A Way Home. In P. Reed \& D. Rottenberg (Eds.), Wisdom in the open air (pp. 157-175). Minneapolis: Minnesota University Press.

Fasting, K. (2009). Born to Move? Perspectives from the Social Sciences. In S. Loland et al. (Eds.), Sport Sciences: Nature, Nurture and Culture. Oslo: European College of Sport Sciences.

Feuerbach, L. (1959). O istocie chrześcijaństwa /On the Essence of Christianity/. Warszawa: PWN.

Feyerabend, P. (1970). Against the Method. Minnesota Studies for the Philosophy of Science, 4.

Feyerabend, P. (1979). Jak być dobrym empirysta /How to Be a Good Empiricist/. Warszawa: PWN.

Fleck, L. (1986). Powstanie i rozwój faktu naukowego. Wprowadzenie do nauki o kolektywizmie myślowym /Coming into Existence and Development of the Scientific Fact. Introduction into Science on Intellectual Collectivism/. Lublin: Wydawnictwo Lubelskie.

Freud, Z. (1967). Czlowiek, religia, kultura /Man. Religion. Culture/. Warszawa: PWN.

Freud, Z. (1975). Poza zasada przyjemności /Beyond the Pleasure Principle/. Warszawa: PWN.

Freud, Z. (1982). Wstep do psychoanalizy /Introduction into Psychoanalysis/. Warszawa: PWN.

Freud, Z. (1995). Kultura jako źródto cierpień /Civilization and Its Discontents/. Warszawa: „KR”.

Godlewski, P. (2005). "Kultura fizyczna” - termin i system na usługach marksistowskiej ideologii /,Physical Culture" - a Term and a System Serving Marxist Ideology/. In Dziubiński, Z. (Ed.) Sport jako kulturowa rzeczywistość /Sport as a Cultural Reality/ (pp. 520-527). Warszawa: Wydawnictwo Poligrafia Inspektoratu Towarzystwa Salezjańskiego.

Gratton, C. \& Taylor, P. (2000). Economics of Sport and Recreation. London: Routledge.

Grössing, S. (1993). Bewegungskultur und Bewegungserziehung. Schondorf: Hofmann.

Grössing, S. (2003). Bewegungskultur. In P. Röthig (Ed.), Sportwissenschaftliches Lexikon 7. Schondorf: Hofmann.

Guttmann, A. (2004). From Ritual to Record: The Nature of Modern Sport. Rev. edn. New York: Columbia University Press.

Hądzelek, K. (Ed.) (1998). Marszałek Józef Pitsudski - patron Akademii Wychowania Fizycznego w Warszawie /Field Marshall Józef Pitsudski - the Patron of University of Physical Education in Warsaw/. Warszawa: AWF.

Hądzelek, K., Rotkiewicz, M., Chełmecki, J., Dorcz, W., Dudek, D. (1998). Rola Józefa Piłsudskiego w rozwoju kultury fizycznej w Polsce i powołaniu Centralnego Instytutu Wychowania Fizycznego /Józef Piłsudski's Role in Development of Physical Culture in Poland and Foundation of the Central Institute for Physical Education/. In Marszałek Józef Pitsudski patron Akademii Wychowania Fizycznego w Warszawie /Field Marshall Józef Pitsudski as the Patron of the University of Physical Education in Warsaw/. Warszawa: AWF.

Hądzelek, K. (2006). Włodzimierz Humen (1944-1972) redaktor naczelny "Wychowania Fizycznego" 19371939 /Włodzimierz Humen (1944-1972) as the Editor-in-Chief of „Physical Education” 1937-1939/. Kultura Fizyczna, 9-12.

Hądzelek, K., Rotkiewicz, M., Chełmecki, J., Dorcz, W., Dudek, D. (2009). Rola Józefa Piłsudskiego w rozwoju kultury fizycznej w Polsce i powołaniu Centralnego Instytutu Wychowania Fizycznego /Józef Piłsudski’s Role in Development of Physical Culture in Poland and Foundation of the Central Institute for Physical Education/. Lider, no. 12.

Hołówka, J. (1981). Relatywizm etyczny /Ethical Relativism/. Warszawa: PWN.

Huizinga, J. (1995). The Nature of Play. In W. J. Morgan \& K. V. Meier (Eds.), Philosophic Inquiry in Sport. Champaign: Human Kinetics.

Hume, D. (1947). Badania dotyczace rozumu ludzkiego /Enquiry concerning Human Understanding/. Kraków: PWN.

Hume, D. (1963). Traktat o naturze ludzkiej /A Treatise of Human Nature/. Warszawa: PWN.

Hume, D. (1974). Związek konieczny /Necessary Connection/. In S. Jedynak Hume. Warszawa: Wydawnictwo „Mysli i Ludzie”.

Jirásek, I. (2005). Filosofocka kinantropologie: sekani filosofie, tela a pohyblu. Olomouc: Vydala Univerzita Palackeho v Olomouci.

Kant, I. (1971). Uzasadnienie metafizyki moralności /Groundwork of the Metaphysics of Morals/. Warszawa: PWN.

Kant, I.(1984). Krytyka praktycznego rozumu /Critique of Practical Reason/. Warszawa: PWN.

Kant, I. (1986). Krytyka czystego rozumu /Critique of Pure Reason/. Warszawa: PWN.

Kmita, J. (1982). O kulturze symbolicznej /On Symbolic Culture/. Warszawa: PWN. 
Kołakowski, L. (2000). Zakresowe i funkcjonalne rozumienie filozofii /Range-Related and Functional Understanding of Philosophy/. In Kultura i fetysze /Kultur and Fetishes/. Warszawa: PWN.

Kosiewicz, J. Kultura fizyczna, osobowość, wychowanie. Zagadnienia metodologiczne /Physical Culture, Personality, Education. Methodological Issues/. Warszawa: Wydawnictwo AWF.

Kosiewicz, J. (1995). W stronę radykalnego i powszechnego agnostycyzmu/Towards Radical and Universal Agnosticism/. Edukacja Filozoficzna, 20.

Kosiewicz, J. (1996). Metodologia jako forma agnostycyzmu /Methodology as a Form of Agnosticism/. Edukacja Filozoficzna, 22.

Kosiewicz, J. (2004a). Filozoficzne aspekty kultury fizycznej i sportu /Philosophical Aspects of Physical Culture and Sport/. Warszawa: Wydawnictwo "BK".

Kosiewicz, J. (2004b). The Universals of Sport - from Realism to Nominalism. In D. Macura, M. Hosta (Eds.), Philosophy of Sport and Other Essays. Ljubljana: Faculty of Sport, University of Ljubljana.

Kosiewicz, J. (Ed.) (2006). Movement Recreation for All. Legionowo: Economical and Technical College in Legionowo.

Kosiewicz, J. (2008). Physical Culture and Sport as a Title of a Periodical and Research Problem. Physical Culture and Sport. Studies and Research, vol. XLV.

Krajewski, W. (Ed.) (1972). Pojęcie prawa nauki a konwencjonalizm XX wieku /The Notion of the Scientific Law and the 20th Century's Conventionalism/. Wrocław.

Kretchmar, R. S. (2009). Do Games Require Artificial Problems that are Neither Too Hard Nor Too Easy?. Typescript of International Association for the Philosophy of Sport Conference Presentation. Seattle Washington, August, 2009.

Kvaløy, Soetereng, S. (1993). Complexity and Time: Breaking the Pyramid's Reign. In P. Reed \& D. Rottenberg (Eds.), Wisdom in the open air. Minneapolis: Minnesota University Press.

Kuhn, T. (1968). Struktura rewolucji naukowych /The Structure of Scientific Revolutions/. Warszawa: PWN.

Lakatos, I. (1995). Pisma z filozofii nauk empirycznych /Works on Philosophy of Empirical Sciences/. Warszawa: PWN.

Leonard Nelson in der diskussion (1994). „Sokratische Philosophieren”. Schriftenreihe der PhilosophishPolitisclien Akademie Herausgegeben von Silvia Knappe, Dieter Krohn, Nora Walter, Band I Herausgegeben von Reingard Kleinknecht i Barbara Neifter. Frankfurt am Main: Dipa-Verlag, Die Deutsche Bibliothek - CIPEinheitsaufnahme.

MacFadden, B. (1926). MacFadden's Encyclopedia of Physical Culture. New York: MacFadden's Publications, INC.

Malcolm, D. (2008). Introduction. In D. Malcolm (Ed.), The Sage Dictionary of Sport Studies. Los Angeles, London, New Delhi, Singapore: Sage.

Matvyeyeff, L. P. (1980). The Formation of the General Theory of Physical Culture. Social Sciences, USSR Academy of Sciences, vol. XI, no. 1.

Matvyeyeff, L. P. (1983). Wwiedienje w teoriu fizyczeskoj kultury. Moskwa: Fizkultura i Sport.

Matvyeyeff, L. P. (1984). Niekatoryje itogi i perspektywy razrabotki obszczejuszczej teorii fizyczeskoj kutury w SSSR. In L. P. Matvyeyeff (sostawitiel i obszczyj redaktor), Oczerki po teorii fizyczeskoj kultury. Moskwa: Fizkultura i Sport.

McNamee, M. \& Bloodworth, A. (2009). Health, Sport and the Good Life: Some Philosophical Remarks. In British Philosophy of Sport Association - $6^{\text {th }}$ Annual Conference. Dundee: University of Abertay Dundee.

McPherson, B. D., Curtis, J. E. \& Loy, J. W. (1989). Defining sport. In B. D. McPherson, J. E. Curtis, J. W. Loy (Eds.), The Social Significance of Sport. Champaign, IL: Human Kinetics.

Meier, K.V. (1995). Triad Trickery: Playing with Sport and Games. In W. J. Morgan \& K.V. Meier (Eds.), Philosophic Inquiry in Sport. Champaign: Human Kinetics.

Merghautowa, J., Joachimstaler, F. (1984). Formirowanie teorii fizyczeskoj kutury w CSRR. In L. P. Matvyeyeff (sostawitiel i obszczyj redaktor), Oczerki po teorii fizyczeskoj kultury. Moskwa: Fizkultura i Sport.

Merghautowa, J., Joachimstaler, F. Cechak, W. (1984). Kriticzeskij obzor niekatorych niemarksistkich koncepcij w teorii fizyczeskoj kultury i sporta. In L. P. Matvyeyeff (sostawitiel i obszczyj redaktor), Oczerki po teorii fizyczeskoj kultury. Moskwa: Fizkultura i Sport.

Moeller, V. (2003). What is sport: Outline to a Redefinition. In V. Moeller \& J. Nauright (Eds.), The Essence of Sport. Odense: University Press of Southern Denmark.

Nelson, L. (1994). O sztuce filozofowania /On Art of Philosophising/. Kraków: Wydawnictwo Baran i Szuszczyński. 
Pearson, K.(2004). The Scientific Life in a Statistical Age. Paris.

Pfister, G. (2007). Local Sport in Europe - National and International Perspectives. Paper presented on $4^{\text {th }}$ European Association for Sociology of Sport Conferences, 31 May - 3 June 2007 Munster, Germany.

Piątkowska, M. (2006). Rozumienie pojęcia kultura fizyczna na świecie/Understanding of the Notion of Physical Culture Across the World/. Kultura Fizyczna, 9-12.

Piłdsudski, J. (1999). W sprawie wychowania fizycznego i sportu /On Physical Education and Sport/. Warszawa: Heliodor.

Poincarè, H. (1908). Nauka i hipoteza/Science and Hypothesis/. Warszawa.

Poincarè, H. (1911). Nauka i metoda/Science and Method/. Warszawa.

Popper, K. (1935). Logik der Forschung. Vienna.

Popper, K. (1977). Logika odkrycia naukowego /The Logic of Scientific Discovery/. Warszawa.

Popper, K. (1992). Wiedza obiektywna. Ewolucyjna teoria epistemologiczna /Objective Knowledge. An Evolutionary Epistemological Theory/. Warszawa.

Przeglad Sportowy (1929). 83.

Reinchenbach, H. (1936). Logistic Empiricism in Germany and the Present State of its Problems. Journal of Philosophy, vol. 33.

Renson, R. (2009). Traditional Sport Games: a Critique of the Western Ethnocentric Approach to Movement. In The Pan-Asian Congress of Sport \& Physical Education. Taipei.

Schmid, S. (2009). Reconsidering Autotelic Play. Journal of the Philosophy of Sport, XXXVI(2).

Sieger, W., Neidhard, H. (1984). O sostojanii i zadaczach teorii fizyczeskoj kutury w GDR. In L. P. Matvyeyeff (sostawitiel i obszczyj redaktor), Oczerki po teorii fizyczeskoj kultury. Moskwa: Fizkultura i Sport.

Suits, B. (1995a). The Elements of Sports. In W. J. Morgan \& K. V. Meier (Eds.), Philosophic Inquiry in Sport. Champaign: Human Kinetics.

Suits, B. (1995b). Tricky Triad: Play, Game and Sport. In W. J. Morgan \& K. V. Meier (Eds.), Philosophic Inquiry in Sport. Champaign: Human Kinetics.

Tomc, G. (2008). The Nature of Sport. In T. Mojca Doupona \& S. Licen (Eds.), Sport, Culture \& Society. Ljubljana: University of Ljubljana.

Wieroński, T. (1937). Testament ideowo-wychowawczy Józefa Pitsudskiego w świetle pism i przemówień /Józef Pitsudski's Ideological Testament in the Light of His Works and Speeches/. Warszawa.

\section{AUTHOR'S ADDRESS: Jerzy Kosiewicz}

Department of Philosophy, Chair of the Social Sciences

Josef Pilsudski University of Physical Education in Warsaw

34 Marymoncka str., 00-968 Warsaw, Poland

Email: jerzy.kosiewicz@awf.edu.pl 